\title{
LIBRARY INSTRUCTION IS A TWO-WAY STREET: STUDENTS RECEIVING COURSE CREDIT FOR PEER TEACHING
}

\author{
by
}

\author{
Jana Ronan and Mimi Pappas
}

\begin{abstract}
Librarians of the George A. Smathers Libraries at the University of Florida, partnered with the Anthropology department to develop a peer-to-peer program to provide outreach to undergraduates taking anthropology courses. The peer instructors, librarians and anthropology department developed a three-credit-hour independent study as a way to compensate the peers for their work. The peer instructors developed a lesson plan, provided classroom and individualized instruction, and developed assessment techniques to evaluate the program. This article discusses the development and implementation of the peer instruction program and presents the results of the surveys.
\end{abstract}

There is a long history of peer teaching in our culture that ranges from the "archons" or student leaders who assisted Aristotle in ancient Greece to the early days of the American school system, when older students attending oneroom schoolhouses routinely instructed their younger peers. What is peer teaching? Lilya Wagner (1980) defined it in her historical examination of the instructional method as "the concept of students teaching other students in formal and/or informal school learning situations which are delegated, planned, and directed by the teacher." In most cases, the peer teachers work individually with students, or in small groups. Students engaged in instructing other students are variously called advisors, teachers, assistants, tutors, leaders, instructors and counselors in the literature, depending upon the services they render and the nature of the program that employs them. We will use the aforementioned terms interchangeably in this article to refer to any student specifically employed to deliver academic, social or instructional services to other students in a college setting. This article will present a new twist on this time-honored instruction method, relating how undergraduate peer instructors at the University of Florida (UF) extended library outreach by teaching library research skills to groups of anthropology undergraduates in a computer lab setting, in conjunction with an academic department for class credit.

Peer teaching, counseling or learning has been used successfully for years by university support services to assist students in adjusting to college. When we decided to investigate the possibilities that peer teaching held for extending our instructional outreach, we discovered that there is a large body of literature detailing the use of peer teachers or counselors in the field of education, and in academic services to college students. These students typically work one-on-one with other students, but also deliver educational presentations to small groups of students. Programs using peer-to-peer education are of ten tied to academic credit and a two or more semester commitment to the program on the part of the peer tutors. Peer advisors, tutors or counselors are frequently enlisted to address issues such as alcohol consumption, sexuality, study skills, stress and multiculturalism among college students. Campus writing centers of ten use peers to reach other college students in need of tutelage in math and writing skills. Russel (1987) notes that $80 \%$ of college orientation programs utilize students to lead tours and other orientation activities. It is a popular method to extend services to college students; at the University of Florida, there are at least 16 programs that utilize peer-to-peer education. In addition, research supports peer programs as an effective means to assist nontraditional and/or minority students in adjusting to college life and helps increase retention (MacAdam, 1996).

While peer involvement in tutoring, orientation, advising and counseling activities is common in university academic and health services, this teaching and outreach technique seems to be slow to catch on in libraries. A review of articles in education and library journals, and responses to an 
informal posting on the ACRL bibliographic instruction listserv, BI-L, revealed that only a handful of libraries use peer-to-peer instruction. When libraries do use peers, they use them to assist at the reference desk, to staff library computer labs or offer assistance with software in library information commons, to staff research paper clinics, and in a very limited fashion in the classroom (Auer, 2001; Avery 2001). By limited, the authors mean that students assist librarians in the classroom by managing computers, by handing out papers, and by roving during hands-on training sessions to keep students on task. Some libraries, such as the University of Michigan's Undergraduate Library, train students to work side-by-side with librarians at the reference desk, answering questions of a directional nature or assisting with software problems and in helping students learn how to use the catalog and general indexes (MacAdam \& Nichols 1989). At Mercy College, information literacy peer tutors provide similar services, with some working in extension sites without librarians (Klavano, 1995). Only a couple of libraries were found to actually use peers to directly enhance and follow-up bibliographic instruction. Binghamton University's Advisory Program is an example of this, with peers that assist librarians with classroom training, then follow up the training by offering students one-on-one tutelage on concepts covered in class (Stelling, 1996). At the University of Maine Libraries at Farmingham, "students assist in all aspects of [the] instruction program" and team-teach classes with librarians (Furlong, 1999). Regardless of the application of peer assistance in library public services, the one thing that is agreed upon is that "peer tutoring can be an effective learning and teaching method... [and] some students do learn better from a peer." (Lindsay, 2000).

\section{Library Instruction at the University of Florida Overview}

The nine libraries of the George A. Smathers Libraries system participate in a comprehensive information literacy program designed to serve approximately 44,000 students at each stage of their research and informational needs. The program consists of four tiers. The first level focuses on basic awareness of library services and resources. Awareness is followed by orientations to library information sources and services, which progresses to introductory training in use of the catalog and an interdisciplinary periodical index for freshmen. This stage of the instruction is implemented largely through the Freshman English Program. The fourth tier of literacy is the stage where librarians teach advanced subject areas and databases to upperclassmen and graduate students. Interested readers can learn more about the UF Libraries' Instruction Program at <http://web.uflib.ufl.edu/ instruct/teach.html>.

The UF Libraries' largest outreach initiative, the Freshmen English Program, is designed to target the university's 6,000 odd incoming freshmen through a core English composition class, ENC1101. Students are oriented to the library system in 50-minute training sessions, and learn basic skills such as use of the library catalog and Expanded Academic Index, an interdisciplinary periodical index. Librarians teach an average of 90 sections of ENC1101 each year, supported by three undergraduate instruction assistants. When not assisting in classes, these undergraduate students compile instructional statistics, revise and prepare handouts, maintain instructional and reference web pages and provide any other kind of help that the teaching librarians might need. In addition, the assistants often aid users in the information commons near the reference desk with basic searching and printing questions.

Despite the wide outreach achieved through the Freshman English Program, librarians are aware of the number of students who miss library training because they do not take ENC1101. A great number of students test out of ENC1101, substitute a technical writing course, or transfer credit from a non-UF composition class. One very visible population of students who have missed this basic instruction are those enrolled in the popular anthropology elective, ANT2301 Human Sexuality. This large lecture class of 500 to 700 requires students to write a research paper exploring some issue relating to sexuality. Like clockwork, a large number of these students line up at the Humanities and Social Sciences Reference Desk each semester the course is offered, waiting for assistance with their papers. Many experience trouble in formulating a narrow enough thesis for the paper, which is understandable as they are often given complex topics as shown below:

"Compare and contrast the marriage customs of two different cultural groups. Be sure to be historically and culturally specific. Discuss the similarities and differences in cultural contexts and social implications for these ceremonies."

Another thing that confounds them is that they are expected to cite at least four refereed journal articles in this paper. Overall, many of these students experience great difficulty in locating appropriate articles and books, and require an orientation to library basics.

The instruction coordinator had been searching for a creative way to extend outreach to these students for some time, to improve their information literacy and to relieve the burden on the reference staff. The challenge was to find ways to teach these students without taxing librarians already overcommitted to teaching in other large-scale instruction initiatives. An unexpected solution to this situation presented itself when one of the instruction assistants approached the library Instruction Coordinator with a proposal to create a peer instruction program targeting these anthropology students.

\section{Peer teaching project}

The instruction assistant who proposed the project, Amy, was a fourth year student majoring in anthropology. Amy and the library Instruction Coordinator brainstormed for quite some time, to figure out a way to offer a peer instruction 
program which would compensate the assistant for her efforts. Offering credit hours through the auspices of the Libraries was not a possibility, but working with the department of Anthropology to supervise a shared independent study was feasible. Discussions ensued between the Chair of the Humanities and Social Sciences Reference Department, the library Instruction Coordinator, the Anthropology bibliographer, Amy and the Undergraduate Coordinator for the Department of Anthropology, which led to the formulation of a three-credit-hour independent study. The focus of the independent study was to teach research and information retrieval skills to first and second year anthropology students. The Anthropology Undergraduate Coordinator was enthusiastic, and recognized the need for more instruction in the use of library resources. She coordinated two independent studies with the Libraries, starting with Amy's in 1999, followed in 2000 by Marina (another instruction assistant with a background in anthropology). After arriving at a mutually satisfactory framework to supervise and evaluate each student as well as to reward them for their work, the next tasks were to formulate goals for the project, to identify the target audience and work out methods for teaching the students and publicizing the project. While librarians thought of the new program as the Peer Teaching Project, both of the students that participated in the project in 1999 and later in 2000 elected to call it the Anthropology Research Skills project.

\section{Goals}

Working with the Anthropology Undergraduate Coordinator, Amy and the library Instruction Coordinator developed the following goals:

1. To target the large number of lower division undergraduate students taking anthropology classes

2. To provide classroom training and individual tutoring in basic library resources. The training was designed to prepare students to learn the following skills:

- Find a book by author/title/subject/keyword

- Identify articles in journals

- Find if the library subscribes to journals

- Evaluate the information sources that they identified

3. To increase student awareness of core anthropology reference works and specialized databases

4. Publicize library services in the Anthropology Department

These goals and objectives dovetailed with the Library Instruction Program's overarching goals of providing basic awareness, orientation and training.

\section{Planning}

The Anthropology Research Skills project began as any project does, with a great deal of planning. Because the peer instructors were also employed by the Libraries as instruction assistants, it was possible for the Instruction Coordinator to assign them planning activities a semester before the project started. This ensured that the Anthropology Research Skills training started promptly in the fall. The library provided the peer teachers with an office and their own computer so that they could have a space where they could plan the project, store their work and consult quietly with students. The office also created a professional atmosphere for consultations. Each peer went through the entire planning process to develop; 1) a script for delivery of instruction, 2) evaluation instruments and strategies, and 3) marketing and communication strategies to encourage students to attend the training labs, office hours and tutoring sessions. The peers also planned the creation of a project website, and completed readings on teaching methodology.

\section{Preparing the peers to teach}

While Amy and Marina had some grounding in teaching from their experience as instruction assistants, training in teaching was still-needed. Assisting with the ENC1101 classes exposed them to a wide variety of different teaching techniques and approaches used by various librarians. Working with students one-on-one during the free searching segment of the classes allowed them to practice their own approaches to teaching. In addition, as preparation for teaching on their own, the students team-taught several classes with the Instruction Coordinator and other librarians. Amy and Marina also completed readings on the subject of library instruction and learning styles. While these experiences helped the peer teachers learn to teach and to build their own unique strengths, more work lay ahead.

\section{Lesson plan and teaching}

The peer teachers planned to teach students in labs scheduled in the Libraries' computer classroom, by individual appointment or by walk-in during the peer teacher's office hours. It was necessary to develop a lesson plan or a script to ensure that students attending the labs would receive consistent information and training. The Instruction Coordinator and the Anthropology Undergraduate Coordinator supervised the peers at every step of preparation, offering suggestions and approving the final script. The foundation of each peer instructor's script was the lesson plan used in the Freshman English Program. This script was revised to use examples from the field of anthropology and expanded to introduce additional databases such as Anthropological Literature and Sociological Abstracts. The searches were carefully chosen to yield consistent results across the databases and to model essential skills for the attendees. An additional component added to the script was a section on the finer points of Boolean searching. These scripts varied slightly from 1999 to 2000, reflecting the peer teacher's own unique teaching style. 


\section{Evaluation}

With a teaching script in place, the peer teachers turned to developing evaluative strategies to measure two factors; 1 ) the attendees' library experiences and 2) the attendees' acceptance of peer teaching as a technique to deliver library instruction. Each peer teacher performed a literature review and read many articles about assessing instruction and developing effective surveys. Finally, each peer teacher created her own survey, the results of which are presented later in this article. The only task left to plan was publicity.

\section{Publicity}

Developing publicity for the project was perhaps the most enjoyable part of the planning process. The peer instructors, the Instruction Coordinator and the Undergraduate Advisor brainstormed together to plan many strategies to get the word out about training to teachers and professors. Methods included 1) posters and flyers with project details and contact information, 2) visits to classes, 3) networking with anthropology faculty and teaching assistants in meetings and by email and 4) developing an informational website for the project.

\section{Implementation}

At the conclusion of the extensive planning stage, the peer teachers, Instruction Coordinator and Anthropology Undergraduate Coordinator began the project by asking Anthropology professors to promote the workshops in their classes. Professors announced the project in their classes, handed out flyers and in some cases gave peers class time to make a short "pitch" for the training. Faculty were somewhat wary at the beginning, but increased their support as they became more familiar with the goals and benefits of the Anthropology Research Skills project. This is in contrast to the graduate teaching assistants, who embraced the project eagerly and encouraged undergraduates to attend training and tutoring sessions.

Announcements in classes were not the only methods of advertising used. The Anthropology Research Skills website featured the peer's contact information, a bibliography of information sources, training lab times and locations, and rosters of attendees. Large 11 "x 14 " posters featuring tear-off tabs with the URL of the project's website were regularly posted in the offices in the anthropology department, accompanied by stacks of the Anthropology bibliographer's extensive reference guide. Flyers were placed in faculty and graduate assistant mailboxes. These posters and flyers featured the URL of website, contact information for the peer teacher and most important of all, times and dates for the training labs. Posters and flyers were also distributed around the Libraries, and librarians used quarter page flyers kept at the reference desks to refer students to the labs. Lastly, Amy and Marina kept in contact with anthropology faculty and graduate teaching assistants by visits and by email, notifying them of upcoming training labs and attendance, which proved to be very effective in marketing the project. Those faculty who made lab attendance mandatory were able to track student compliance by consulting the rosters on the project website.

The peer teachers offered several different types of training to accommodate learning preferences. There were scheduled labs for hands-on group instruction, walk-in of fice hours and scheduled tutoring sessions. The hands-on training labs proved to be the most popular method of reaching the students. While students were encouraged to sign up for the labs, many students just showed up for training, especially as the end of the term grew near. Training labs held later in the semester were much better attended than the ones offered earlier in the semester. The peer instructors also learned to "wing it" as many insiruction librarians do in the real world. They learned to adjust the pacing of the delivery to meet the needs of the audience and they learned voice modulation. They also learned strategies for troubleshooting problems that arose during the lab sessions, such as network crashes, slow databases and database connectivity problems. One peer instructor even arranged a spontaneous lab for a section of 20 students when their teaching assistant brought them into the library without warning. There were 6 labs offered in 1999 and 5 in 2000. In 1999 few students took advantage of the one-on-one options, while in 2000 the attendance was more equally distributed between labs and one-on-one sessions. The attendance in 2000 was more equally distributed between labs and one-on-one sessions, with even some repeat customers. A total of 49 students received training in 1999, and 44 in 2000.

\section{Results Attendee response to the peer instructors}

At the end of each tutoring or training sessions, students were given surveys to complete. Selected results are given in the table in Figure 1.

Because the peer teachers were given freedom to develop their own evaluation instruments for their independent studies as a learning experience, the surveys handed out during the two semesters were not identical. The tables above compare questions that the instruments had in common, even though they were sometimes worded or formatted slightly differently on the actual surveys.

The responses indicated that we did reach a large number of untrained freshmen students; $73 \%$ of the respondents in 1999 and $63 \%$ in 2000 had never attended a general library training session. This confirmed anecdotal information from reference librarians that the ANT2301 Anthropology classes were an important area in which to extend outreach.

A key question on both surveys was question number 5 , which concerned the comfort level of the attendees with peerto-peer instruction. This was a free-response question and students were given space to explain whether they, "felt more comfortable being taught by the undergraduate instructor" 
Figure 1: Anthropology Research Skills Attendees Survey

\begin{tabular}{|c|c|c|}
\hline Question & Fall 1999 & Fall 2000 \\
\hline $\begin{array}{l}\text { 1. What year are } \\
\text { you? }\end{array}$ & $\begin{array}{l}\text { 79\% Freshmen, } \\
\text { Sophomores }\end{array}$ & $\begin{array}{l}78 \% \text { Freshmen, } \\
\text { Sophomores }\end{array}$ \\
\hline $\begin{array}{l}\text { 2. How often do } \\
\text { you come to the } \\
\text { library? }\end{array}$ & $\begin{array}{l}77 \% \text { Daily, } \\
\text { Weekly or } \\
\text { Monthly }\end{array}$ & $\begin{array}{l}50 \% \text { Daily, } \\
\text { Weekly or } \\
\text { Monthly }\end{array}$ \\
\hline $\begin{array}{l}\text { 3. Do you think } \\
\text { the library } \\
\text { should offer } \\
\text { instruction in } \\
\text { how to use the } \\
\text { library? }\end{array}$ & $95 \%$ Yes & $\begin{array}{l}90 \% \text { Agree or } \\
\text { Strongly Agree }\end{array}$ \\
\hline $\begin{array}{l}\text { 4. Would you } \\
\text { prefer a class- } \\
\text { room setting or } \\
\text { individualized } \\
\text { instruction? }\end{array}$ & $\begin{array}{l}71 \% \text { Classroom } \\
\text { or Both }\end{array}$ & $56 \%$ Classroom \\
\hline $\begin{array}{l}\text { 5. Did you feel } \\
\text { more comfort- } \\
\text { able being } \\
\text { taught by the } \\
\text { undergraduate } \\
\text { instructor than } \\
\text { you would have } \\
\text { with a librarian? }\end{array}$ & $61 \%$ Yes & $69 \%$ Yes \\
\hline $\begin{array}{l}\text { 6. Have you } \\
\text { ever attended a } \\
\text { general library } \\
\text { training ses- } \\
\text { sion? }\end{array}$ & $73 \%$ No & $63 \%$ No \\
\hline
\end{tabular}

than a librarian. Responses were interpreted and broken down into the categories of either positive responses, negative responses or neutral responses. Most respondents $(61 \%$ and $69 \%)$ indicated that they were comfortable with an undergraduate teaching the sessions. Attendees commented that the peer was "more on my level than a librarian would be," and "less intimidating." One person wrote, "she seemed to want to answer the questions, teaching me 'how to fish', not just giving me the fish." We interpreted that answer to mean that the attendee thought the peer teacher was interested in teaching the students the process of finding information on their own, rather than supplying quick answers. Another student commented that, "Being taught by one of my peers made me feel more at ease." The neutral and negative responses to the comfort level question were very similar to each other in that the respondents indicated that they did not have a preference for educational level as long as the instructor was competent. Some selected neutral or negative responses were, "Either way is ok by me;" Comfortable with either," and "I didn't realize that these titles were mutually exclusive." We were troubled by the last comment, but awareness of educational preparation for librarians is a topic that does not fit the purview of this article.

The attendees indicated a very positive experience with training as a whole, a question that was not represented on the table above; it was phrased differently on the two instruments. The fall 1999 survey asked, "Please rank your overall experience in this library training session," and asked attendees to use a sliding scale to rank the experience from Poor to Excellent. $83 \%$ responded Good or Excellent. The peer teacher for fall 2000 modified that question for her survey and asked students to rank their overall experience for Content (86\% Excellent), Pacing of Delivery (82\% Excellent), and Instructor's Knowledge of Content (86\% Excellent).

The question, "How did you hear about this training session?" was also not included in the table because it was asked in fall 2000 only. $63 \%$ of the respondents answered that they heard about the training sessions via the marketing presentations the peer teacher made in the anthropology classes. The response to this question was meaningful to our instruction librarians, as it indicated that visits to classes are important when advertising library outreach.

Another free-response question, "What new information did you learn from this training session?" was not included in the table but the responses indicate that we were meeting our goal of reaching students who were in great need of basic information about the libraries. Students wrote that they learned: "How to find journals;" "more understanding of computer library system;" "new databases for anthropology;" "how to research for my coming paper;" and "how to use my library effectively." These responses and the rest of the responses to this question, which were similar, told the librarians that the attendees gained valuable information from the peer teachers' labs and assistance.

\section{How the librarians benefited from the project}

The librarians profited greatly from the Anthropology Research Skills project. The peers trained many undergraduates who would not have been reached through the existing outreach efforts. In addition, the relationship between the library and the Anthropology department was strengthened leading to a systematic program to work with every section of the ANT2301 students.

An unexpected outcome of the project was that the peer instructors refreshed the librarians' outlook on library instruction. The project was in many ways as much a learning experience for the librarians as for the peer teachers. The in-depth conversations with the peers about teaching philosophy, goals and learning styles helped us to see where we had gotten mired in old habits. In many cases instruction librarians learned new, and more concise ways to deliver 
content that had become rote. Working with the peer instructors provided the unique opportunity to see the library through a student's eyes.

\section{How the peer teachers benefited from the experience}

While the librarians benefited greatly from having the peer instructors teach classes the peer instructors may have gained more. One wonderful benefit for the students was that they were able to receive academic credit for a project that they had a voice in creating and that held deep interest for them. The independent study developed into an honors thesis for one of the peer teachers. They not only learned advanced skills in using library databases and resources, but also gained experience in how to perform an extended research project involving survey data. The project was a practicum in performing effective instruction, starting with lesson planning, then teaching and finally assessment.

\section{Conclusions and future directions}

The peer teacher project presented some challenges and successes. The hard work of the peer teachers, the librarians and the Anthropology Undergraduate Coordinator met our goals and opened new doors. An exciting outcome that we did not expect was a new partnership between the library and the anthropology department to provide a more formal program of outreach for ANT 2301.

The peer teachers were very happy with receiving course credit for a project that they were able to develop. We don't know if their experiences in the peer-teaching project were influential, but both Amy and Marina are currently completing library science degrees. And we are so pleased with the success of the peer-to-peer teaching methodology that we are looking for new ways to incorporate it into library instruction.

As we think of new ways to utilize our student assistants we keep these words from Gartner and Reissman (1999) in mind, "Young people are influenced far more by each other than they are by parents, teachers, or other authority figures. They talk the same language, and they listen to each other far more than to adults. They model themselves on other young people. Behavioral science research suggests that people are more likely to hear and personalize messages resulting in changing attitudes and behaviors if they believe the messenger is similar to themselves and faces the same concerns and pressures. Peer education draws on the credibility that young people have with their peers, leverages the power of role modeling, and provides flexibility in meeting the needs of today's youth."

\section{References}

Auer, N. (2001, April 19.) Peer Advisors. BI-L. [Online]. Available Email: BI-L@listserv.byu.edu.

Avery, B. (2001, April 19.) Peer Advisors. BI-L. [Online]. Available Email: BI-L@listserv.byu.edu.
Edwards, J., Patterson, M. \& Gleeson, A. (1999, June). Seize the Moment: How to Use Peers as Teachers to Expand Your Instruction Program. Poster session presented at the annual meeting of the American Library Association, New Orleans, LA.

Furlong, K. (2001, April 19.) RE: Peers in Instruction. BIL. [Online]. Available Email: BI-L@listserv.byu.edu.

Furlong, K., Nicotera, C. \& Reny, J.A. (1999, October). What's In It For Me? A Student's Look at TechnologyEnhanced Teaching in the College Library. Poster session presented at the annual meeting of EDUCAUSE, Long Beach, CA.

Deese-Roberts, S. \& Keating, K. (2000). Library Instruction: A Peer Tutoring Model. Englewood, CO: Libraries Unlimited.

Gartner, A. \& Reissman, F. (1999). The Future of the Peer Movement. Social Policy, 30(1), 5.

Klavano, A. M. \& Kulleseid, E. R. (1995). Bibliographic Instruction: Renewal and Transformation in One Academic Library. Reference Librarian, 51-52, 359-83.

Lindsay, E. B. (2000, Winter). Undergraduate Students as Peer Instructors: One Way to Expand Library Instruction and Reference Services. LOEX News, pp. 7, 13,16.

MacAdam, B. \& Nichols, D. P. (1988) Peer Information Counseling at the University of Michigan Undergraduate Library. The Journal of Academic Librarianship, 14(2), 80-81.

MacAdam, B. \& Nichols, D. P. (1989). Peer Information Counseling: An Academic Library Program for Minority Students. The Journal of Academic Librarianship, 15(4), 204-209.

Russel, J. H. \& Thompson, D. (1987). Evaluation of a Program of Peer Helping for 1st-Year Students. Journal of College Student Personnel, 28(4), 330-36.

Russell, J. H. (1986). Peer Counseling: Establishing a Network in Training and Supervision. Journal of Counseling and Development (64), 457-459.

Stelling, P. (1996). Student to Student: Training Peer Advisors to Provide BI. Research Strategies 14(1), 5055 .

Wagner, L. (1980). A Historical Base and Rationale for Peer Teaching. (Doctoral dissertation, University of Florida, 1980). Dissertation Abstracts International, 41, 05A.

Jana Ronan is Program Director for Undergraduate Library Services, Humanities \& Social Sciences Services at George A. Smathers Libraries, University of Florida, Gainesville, FL 32601-7011, USA. Phone: (352) 392-4919 ext. 1711; E-mail: jronan@ufl.edu

Mimi Pappas is Instruction Coordinator for the Freshmen English Program, Humanities \& Social Sciences Services, George A. Smathers Libraries, University of Florida Gainesville, FL 32601-7011, USA. Phone: (352) 392-4919 ext.1724; E-mail:mimipa@ufl.edu 